\title{
PŘÍSPĚVEK K POZNÁNÍ TVRZIŠTĚ V ČESKÝCH LIBCHAVÁCH NA ÚSTECKOORLICKU
}

\author{
DAVID VÍCH
}

\begin{abstract}
Abstrakt: Zatímco písemné prameny datuji tvrziště v Českých Libchavách do druhé poloviny 14.-16. století, kolekce nově získaných movitých nálezů ukazuje na osidlení ve 14. století, popř́padě v první polovině 15. století. Relikt komunikace v bezprostředni blizkosti lokality připouští stejné datování, movité nálezy v̌sak neposkytl.
\end{abstract}

Klíčová slova: tvrziště - vrcholný středověk - keramika - železné předměty.

\section{Contribution to the Information about a Manor Site in České Libchavy, in the Ústí nad Orlicí Region}

Abstract: While written sources date the manor site in Česke Libchavy to the second half of the 14th-16th century, a collection of recently excavated items points towards settlement in the 14th century, or in the first half of the 15th century. Remains of a communication in close proximity of the location allow for the same dating; however, no material finds have been unearthed.

Key words: manor site - high Middle Ages - pottery - iron objects.

V roce 2008 bylo při kontrolní návštěvě lokality zjištěno značné narušení tvrziště v Českých Libchavách (okr. Ústí nad Orlicí, Pardubický kraj; obr. 1,2) nelegálními uživateli detektorů kovů, o čemž svědčily četné vkopy především na ploše vlastního areálu tvrziště, ale i v prostoru př́ikopů. Zatímco v některých vkopech se ještě válel recentní železný odpad (obr. 3), jiné byly prázdné, což dokládalo zájem výkopce o detekovaný předmět. Vzhledem k minimu dosud známých informací o lokalitě bylo rozhodnuto provést zde povrchovou prospekci včetně využití detektoru kovů s př́slušnou dokumentací (dokumentace stratigrafie jednotlivých mikrovrypů, zaměření ruční stanicí GPS a zároveň zanesení do plánu lokality) s cílem vyzvednout předpokládané zbylé kovové předměty a pokusit se získat i případné další movité archeologické nálezy, především keramiku. Po ojedinělých individuálních akcích byla $\mathrm{z}$ technických a časových důvodů zorganizována jednorázová akce většího rozsahu až v roce 2012 (přičemž nelegální vkopy zde byly registrovány ještě v roce 2014). Celková časová dotace detektorového průzkumu tvrziště činí po přepočítání na jeden př́ístroj 55 hodin s využitím přístrojů Fisher 1270, Minelab GPX 4500, Garrett Ace 250, F 75, XP Gmaxx, XP Deus, Minelab E-TRAC, Tesoro Cortes. Pozornost byla vedle bezprostředního okolí tvrziště věnována i reliktu komunikace nacházející se východně od lokality, který ústí do prostoru prríkopu a s tvrzištěm s největší pravděpodobností souvisí (obr. 1, výřez).

Tvrziště s pomístním názvem „Skalka“ se nachází v nadmořské výšce lehce přesahující hodnotu $400 \mathrm{~m}$ n.m. v severní části k. ú. České Libchavy východně od intravilánu v zalesněném prostoru nad údolím Libchavského potoka (obr. 1:A) přes údolí naproti kostelu sv. Víta pocházejícího ze 14. století (Poche a kol. 1977, 209). Plochu památky přibližně obdélného půdorysu od okolního terénu z jižní, východní a západní strany vymezuje hluboký př́ikop, v západní a částečně i jižní části doplněný valem, na straně severní zakladatelé využili přírodní strž. V takto vymezeném prostoru je v západní části situována obdélná deprese představující pravděpodobně suterén věžové stavby, která je dnes silně narušena vkopy patrně souvisejícími se stavbou provizorního př́ístřešku. Při severní a jižní hraně plochy tvrziště se nachází mělké deprese neznámého, nicméně nepochybně druhotného původu. Severně od areálu tvrziště jsou patrné pozůstatky nevelké zděné stavby přibližně čtvercového půdorysu novověkého stáří.

Do př́íkopu v severovýchodní části tvrziště ústí cesta zahlubující se v délce 31 metrů 4-6 metrů hluboko do skalního podloží (obr. 4). Po opuštění tohoto zahloubeného úseku směřujícího přibližně $\mathrm{k}$ jihovýchodu se komunikace postupně stáčí $\mathrm{k}$ jihu až jihozápadu do intravilánu Českých Libchav (obr. 1, výřez).

Území kolem Libchavského potoka poprvé vstupuje do písemných pramenů v roce 1227 , kdy les na území nynějších Libchav („Nalubhaue“) daroval Kojata z Hrabišic svému družiníkovi 


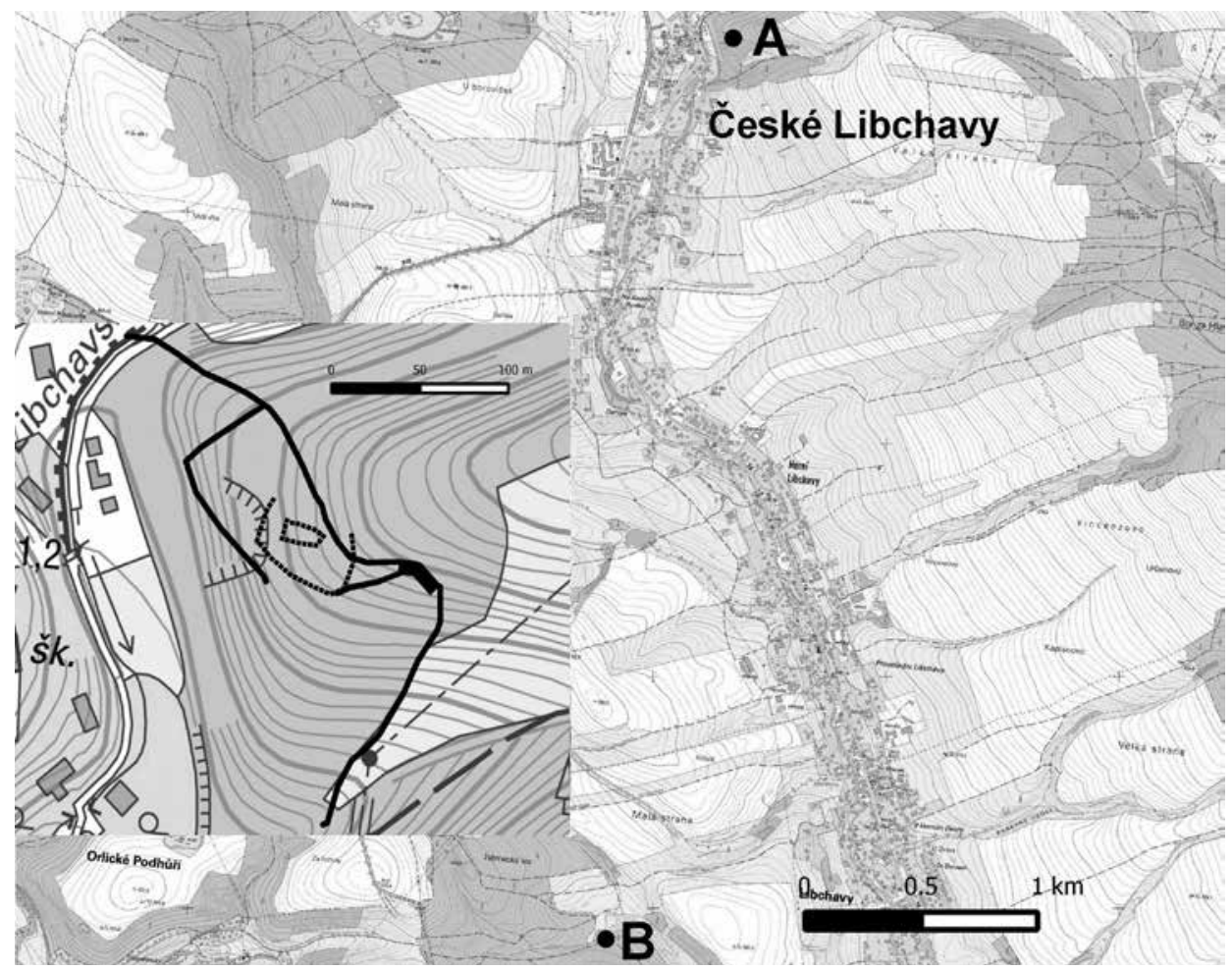

Obr. 1. České Libchavy. A - poloha tvrziště, B - místo nálezu třmene v Dolních Libchavách. Ve výřezu detail s komunikačním schématem. Zahloubený úsek cesty zvýrazněn tučně, prostor tvrziště s př́íkopem přerušovaně. Měřeno ruční stanicí GPS Garmin eTrex 20, zpracováno v programu Quantum GIS.

Abb. 1. České Libchavy. A - Lage der Festungsstätte, B - Fundort des Bügels in Dolní Libchavy. Im Ausschnitt Detail mit Verkehrswegeschema. Eingetiefter Wegabschnitt fett, Raum der Festungsstätte mit Graben gestrichelt. Vermessen mit einem GPS Handgerät Garmin eTrex20, erstellt mit dem Programm Quantum-GIS.

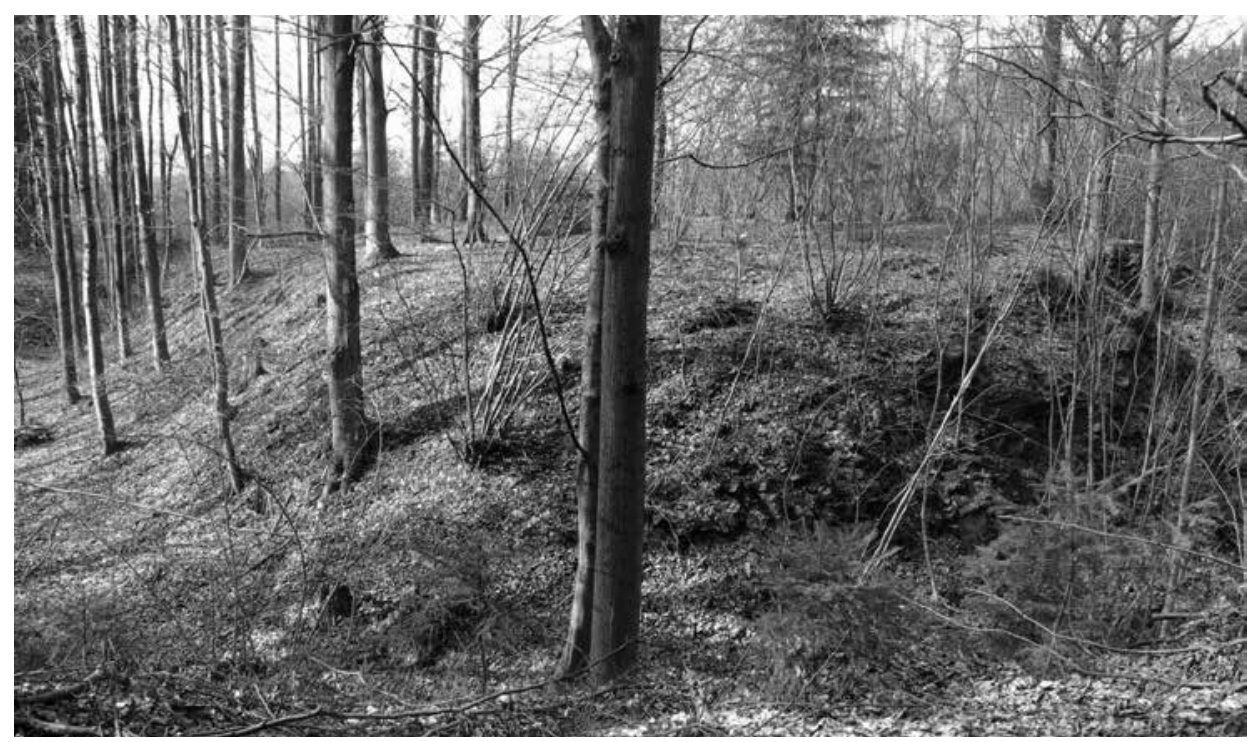

Obr. 2. České Libchavy. Tvrziště, pohled k severozápadu. Foto D. Vích, 1. 4. 2014.

Abb. 2. České Libchavy. Festungsstätte, Blick nach Nordwesten. Foto D. Vích, 1. 4. 2014. 


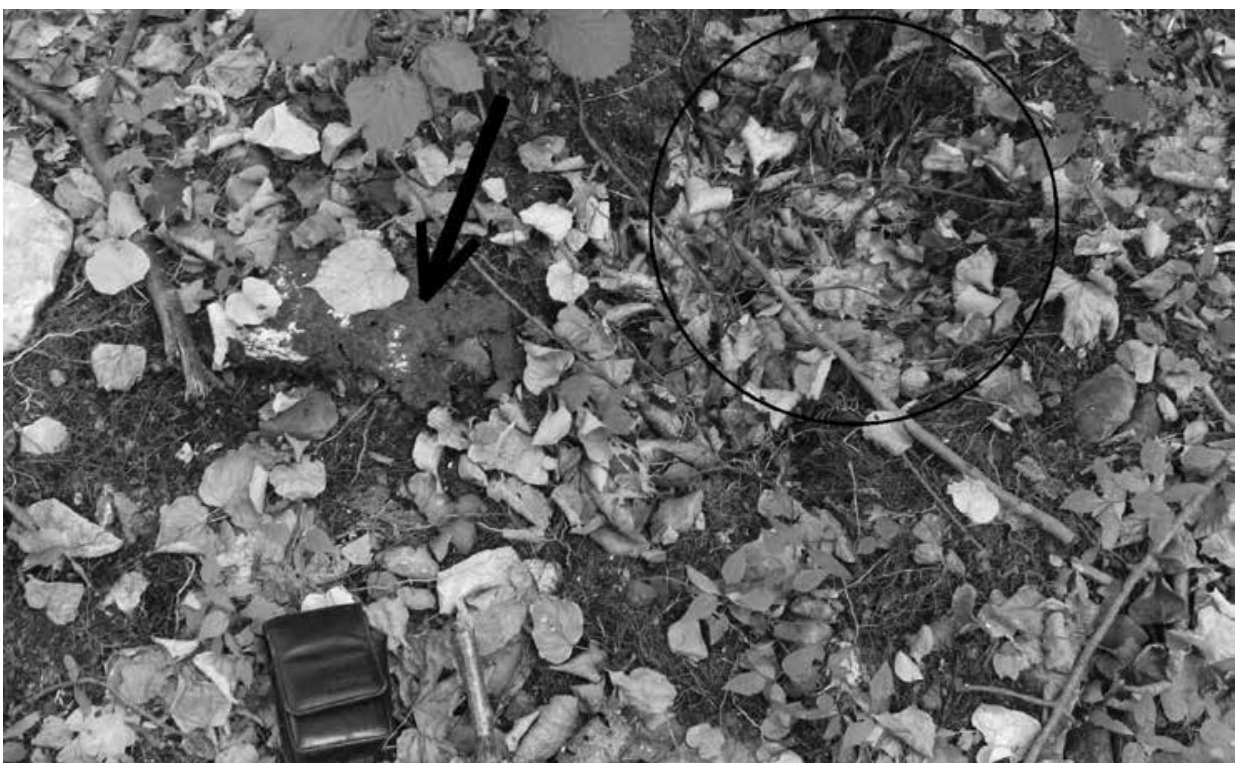

Obr. 3. České Libchavy. Př́íkop u tvrziště. Výkop detektorového původu (vyznačeno elipsou) s pohozeným kusem železa (vyznačeno šipkou). Foto D. Vích, 28. 8. 2008.

Abb. 3. České Libchavy. Graben bei der Festungsstätte. Auf einen Detektor zurückgehender Aushub (Ellipse) mit einem weggeworfenem Stück Eisen (Pfeil). Foto D. Vích, 28. 8. 2008.

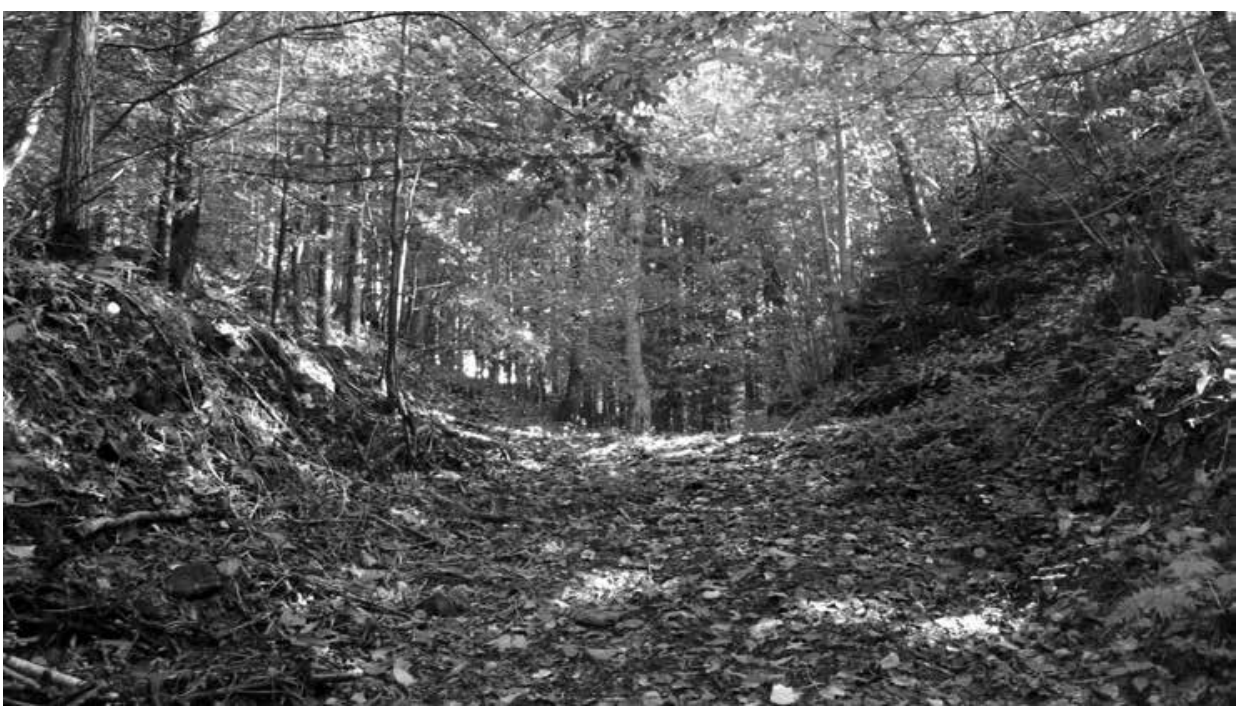

Obr. 4. České Libchavy. Vyústění cesty do př́íkopu u tvrziště, pohled k východu. Foto D. Vích, 22. 9. 2014.

Abb. 4. České Libchavy. Wegmündung in den Graben bei der Festungsstätte, Blick nach Osten. Foto D. Vích, 22. 9. 2014.

(CDB II, 301 č. 303). Vlastní obec poprvé vstupuje do písemných pramenů v roce 1360 jako majetek Petra Hrba ze Žamberka. V letech 1397-1415 se po Českých Libchavách psal Jindřich z Českých Libchav a Brandýsa, v letech 1440-1447 Mikeš z Českých Libchav. Kdo byl zakladatelem tvrze, však nevíme, ta je poprvé výslovně uvedena až k roku 1543, kdy již České Libchavy patřily k žampašskému panství. Roku 1574 byla tvrz s dalším zbožím prodána a dále se v písemných pramenech neobjevuje (Sedláček 1883, 146). 
Archeologický výzkum na lokalitě dosud neproběhl a nebyly zde známé ani movité archeologické nálezy, proběhlo pouze zaměření lokality (Cejpová 2003). Na katastru obce České Libchavy tak dosud archeologické nálezy reprezentovaly pouze mince. K depotu brakteátů a feniků objevenému roku 1914 na břehu potoka při hře dětí (Nohejlová-Prátová 1956, 94-95; Petrtyl 1966, 14), vrcholně středověkému depotu z dob husitských válek nalezenému v nádobce na zahradě pana Papáčka v roce 1933 (Nohejlová-Prátová 1956, 192) a novověkému depotu objevenému roku 1923 v domě čp. 17 při kopání základů k nové stavbě po požáru (Nohejlová-Prátová 1957, 28; Petrtyl 1966, 21) nedávno přibyl nález dukátu Ladislava V. objevený detektorem kovů pravděpodobně v místech při soudobé komunikaci (Militký-Vích 2010).

O mnoho lépe na tom $\mathrm{s}$ archeologickými nálezy nejsme ani v širším okolí Českých Libchav. Z movitých archeologických nálezů byly známé zatím pouze vrcholně středověké zlomky keramiky objevené u čp. 101 či 102 v Horních Libchavách (Vích 2006, 5, tab. 5:2091-2096) a nedávno získané nečetné novověké a patrně i vrcholně stř̌edověké zlomky objevené povrchovým sběrem u čp. 174 v Dolních Libchavách (Vích 2014, 236), přičemž z Horních i Dolních Libchav známe stavby označované jako tvrziště (k nim Musil 1995, 25-26, 30; Musil-Gilar 2002). Tuto kolekci nově rozšiřuje asymetrický železný třmen objevený panem F. Páclem na k. ú. Dolní Libchavy a následně předaný do Regionálního muzea ve Vysokém Mýtě, který může být dokladem komunikace, stejně jako loveckých aktivit (obr. 5). Předmět lze klasifikovat jako typ VI, varianta A, s výskytem od 15. století (Swiętosławski 1990, 58-60), v rámci našeho území bohužel postrádáme (podobně jako u dalších vrcholně středověkých kovových předmětů) pro třmeny souhrnnou práci, která by umožnila tuto kategorii nálezů vyhodnotit. Na základě bohatého souboru kovových nálezů ze Sezimova Ústí se třmenům naposledy věnoval R. Krajíc, který však problematice asymetrických třmenů vzhledem $\mathrm{k}$ jejich absenci v sezimovoústeckém souboru nevěnuje pozornost (Krajíc 2003, 116). Do 15. století jsou datovány analogické třmeny např. z šarišského hradu (Slivka 1980, 257, obr. 17:3), Posádky pri Gajaroch (Polla 1962, 137, obr. 8:8, 18:1, 3, 4, 6), Vízmburku (Hejna 1983, 496, obr. 5:4; Koštál a kol. 2013, 186, obr. 77:1), Vartnova (Kouřil-Prix-Wihoda 2000, 557, obr. 264:2-3) či Dolan (Burian 1981, 27).

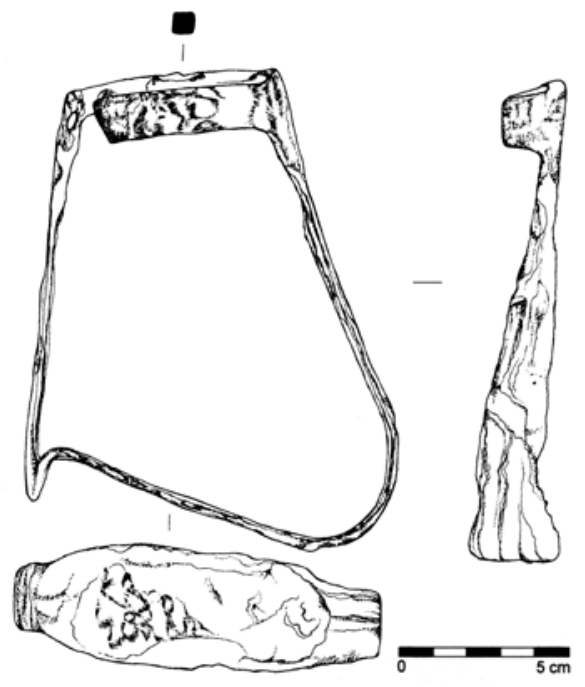

Obr. 5. Dolní Libchavy. Ojedinělý nález třmene. Kresba M. Schindlerová.

Abb. 5. Dolní Libchavy. Einzelfund eines Bügels. Zeichnung M. Schindlerová.
Při průzkumech v letech 2008-2012 (povrchové sběry až do r. 2014) se v areálu tvrziště podařilo shromáždit celkem 29 ks kovových předmětů, které se soustřed'ovaly do areálu tvrziště, mimo vlastní areál vymezený příkopy se ojediněle vyskytly západně od prííkopu v jeho blízkosti. Dále se podařilo získat celkem 76 ks zlomků keramiky. Nejčastěji se vyskytovaly $\mathrm{v}$ bezprostředním okolí zahloubeného suterénu stavby projevující se jako terénní deprese, další nálezy byly objeveny rovněž v druhotně vzniklé depresi při severním okraji tvrziště a ve splachu na svahu do př́kopu severně od zahloubeného suterénu. Všechny prezentované předměty z Českých Libchav jsou majetkem Pardubického kraje a jsou uloženy v Regionálním muzeu ve Vysokém Mýtě v podsbírce archeologie pod inv. č. 5004-5006, 5714-5718, 6666-6691, 6692-6694. 


\section{Keramika}

V souboru keramiky se hojně vykytuje šedá redukčně pálená keramika, ale výjimkou není střep špinavě bílé barvy. Ojediněle se objevuje i archaicky vyhlížející keramická hmota rezavé barvy s příměsí slídy. Tuhovou keramiku reprezentuje drobný omletý střípek a dva zlomky patrně z téže zásobnice ( $v$ jednom prrípadě z přechodu dno - stěna), které jsou na vnějším povrchu přetaženy červenohnědou až hnědou engobou. Výzdobu keramiky tvoří především různé vodorovné žlábkování (ukázka obr. 6:2), v jednom případě se objevila vývalková šroubovice na střepu z jemné bílé keramické hmoty. Třikrát se vyskytlo červené malování (obr. 6:3-4), v jednom př́ípadě na zlomku prožlabeného páskového ucha (obr. 6:4). Zlomky den nesou bez výjimky stopy podsýpky, odřezání strunou se nevyskytuje vůbec. Okraje se neobjevují příliš často, pokud ano, jde především o různé formy uvnitř prožlabených okruží (obr. 6:1, 7, 8). Z keramických tvarů dokážeme identifikovat pouze hrnce, výskyt jiných tvarů nejsme s to ve značně fragmentarizovaném materiálu rozpoznat. Celkově až na výjimky působí soubor poměrně archaickým dojmem, ovšem keramika, která by jednoznačně náležela 13. století, v souboru chybí. Přes velmi nedostatečnou znalost východočeské keramiky 14.-15. století odpovídá datace souboru zprávám v písemných pramenech o osídlení ve 14.-15. století, přičemž však pro 14. století připadá v úvahu i vyšší stáří než pouze jeho druhá polovina. Na druhé straně zcela chybí keramika pozdního středověku, či dokonce novověku, kdy je tvrz explicitně poprvé zmiňována.
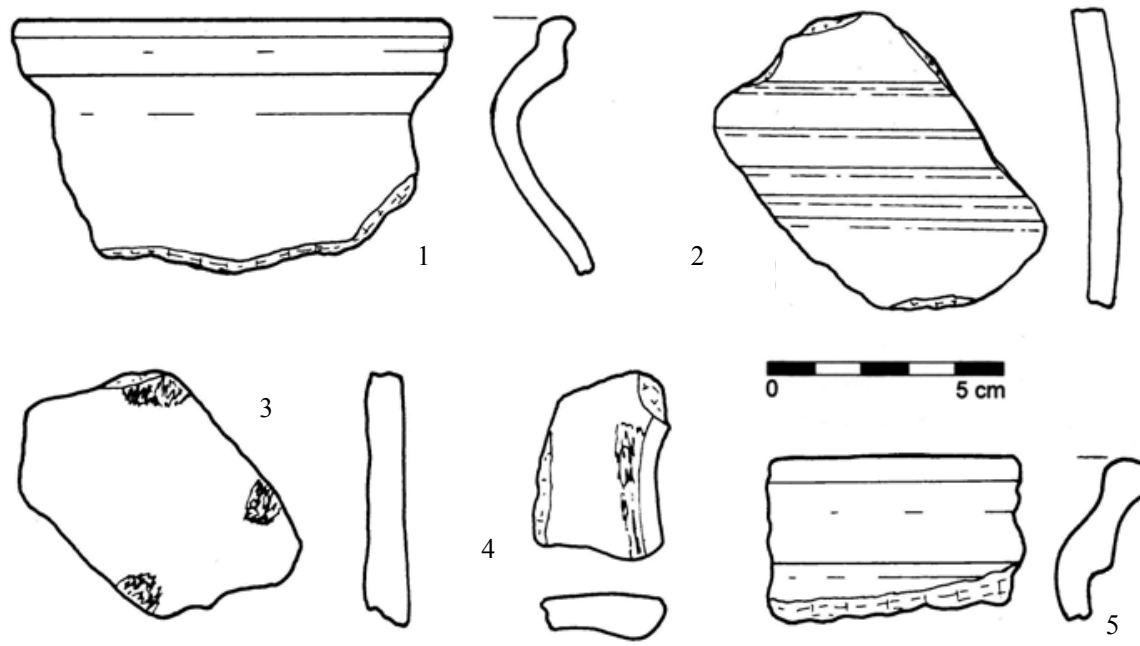

6
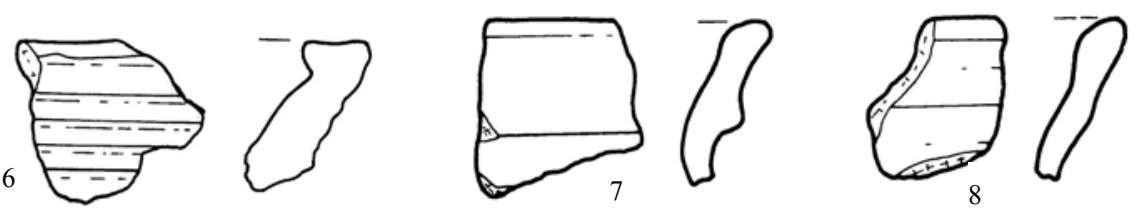

Obr. 6. České Libchavy. Zlomky keramiky z tvrziště. Kresba D. Vích.

Abb. 6. České Libchavy. Keramikfragmente von der Festungsstätte. Zeichnung D. Vích. 


\section{Kovové předměty}

\section{Militaria}

2. hrot šípu s trnem, $78 \times 14 \times 10 \mathrm{~mm}$, hl. $6 \mathrm{~cm}$ v šedohnědé povrchové humusové vrstvě (obr. 7:1)

3. hrot šípu s trnem, $96 \times 10 \times 9 \mathrm{~mm}$, hl. $10 \mathrm{~cm}$ na rozhraní humusové vrstvy a vrstvy kamenů s keramikou při okraji terénní deprese (obr. 7:2)

10. fragment třmene kruhového tvaru se zesilujícím žebrem, $108 \times 50 \times 7 \mathrm{~mm}, \mathrm{hl} .25 \mathrm{~cm}$, $\mathrm{z}$ toho $18 \mathrm{~cm}$ v okrovošedém rozpadlém skalním podloží pod velkými kameny (velikost ojediněle až do $60 \mathrm{~cm}$; obr. 8:7)

17. hrot kopí s odlomenou tulejí, $206 \times 26 \times 25 \mathrm{~mm}, \mathrm{hl}$. $16 \mathrm{~cm}$, z toho $11 \mathrm{~cm}$ v okrovošedém eluviu mezi kameny (do $15 \mathrm{~cm}$; obr. 7:7)

18. hrot šípu s odlomenou tulejí, $75 \times 19 \times 16 \mathrm{~mm}, \mathrm{hl} .12 \mathrm{~cm}, \mathrm{z}$ toho $5 \mathrm{~cm}$ v okrovošedém rozpadlém skalním podloží (obr. 7:3)

19. hrot šípu s odkorodovaným trnem, $56 \times 11 \times 9 \mathrm{~mm}$, hl. $18 \mathrm{~cm}$, z toho $14 \mathrm{~cm}$ v okrovošedém rozpadlém skalním podloží (obr. 7:6)

20. hrot šípu s trnem, $85 \times 10 \times 8 \mathrm{~mm}$, hl. $17 \mathrm{~cm}$, z toho $13 \mathrm{~cm}$ v okrovošedém rozpadlém skalním podloží (obr. 7:13)

21. hrot šípu s odkorodovaným trnem, $61 \times 12 \times 13 \mathrm{~mm}$, hl. $14 \mathrm{~cm}$ v okrovošedém rozpadlém skalním podloží (obr. 7:15)

22. hrot šípu s trnem, $74 \times 10 \times 11 \mathrm{~mm}$, hl. $12 \mathrm{~cm}$, z toho $10 \mathrm{~cm}$ v okrovošedém rozpadlém skalním podloží pod kořenem (obr. 7:14)

23. hrot šípu s recentně částečně odlomeným trnem, $88 \times 14 \times 11 \mathrm{~mm}, \mathrm{hl} .19 \mathrm{~cm}, \mathrm{z}$ toho $10 \mathrm{~cm}$ v okrovošedém rozpadlém skalním podloží (obr. 7:10)

24. hrot šípu s recentně ohnutým trnem, $81 \times 14 \times 12 \mathrm{~mm}, \mathrm{hl} .20 \mathrm{~cm}$, z toho $8 \mathrm{~cm}$ v okrovošedém rozpadlém skalním podloží (obr. 7:11)

25. hrot šípu s recentně ohnutým trnem, $88 \times 15 \times 14 \mathrm{~mm}, \mathrm{hl} .14 \mathrm{~cm}$, z toho $6 \mathrm{~cm}$ v okrovošedém rozpadlém skalním podloží (obr. 7:8)

26. hrot šípu s částečně odkorodovaným trnem, $78 \times 14 \times 10 \mathrm{~mm}, \mathrm{hl} .16 \mathrm{~cm}, \mathrm{z}$ toho $6 \mathrm{~cm}$ v okrovošedém rozpadlém skalním podloží mezi kameny (obr. 7:12)

27. hrot šípu s částečně odkorodovaným trnem, $73 \times 14 \times 12 \mathrm{~mm}, \mathrm{hl} .15 \mathrm{~cm}$, z toho $5 \mathrm{~cm}$ $\mathrm{v}$ okrovošedém rozpadlém skalním podloží mezi kameny (obr. 7:5)

28. hrot šípu s trnem, $115 \times 11 \times 7 \mathrm{~mm}$, hl $16 \mathrm{~cm}$, z toho $8 \mathrm{~cm}$ v okrovošedém rozpadlém skalním podloží mezi kameny (obr. 7:4)

29. hrot šípu s odkorodovaným trnem, $74 \times 13 \times 10 \mathrm{~mm}, \mathrm{hl} .20 \mathrm{~cm}$, z toho $10 \mathrm{~cm}$ v okrovošedém rozpadlém skalním podloží mezi kameny (obr. 7:9)

Celkem 13 exempláŕů (obr. 7:1-2, 4-6, 8-15) z celkových 14 kusů hrotů šípů náleží skupině A $1 b$ podle T. Durdíka (1972), popř. A, typu II v pojetí R. Krajíce s datací do druhé poloviny 13. století a první poloviny 14 . století $(2003,186$, obr. 150,153$)$, skupině B typu 11 v pojetí A. Ruttkaye (1976, Abb. 54) s datací do 13. nebo počátkem 14. století (Ruttkay 1976, 331, Abb. 54) či D 2-4, zde s časnějším datováním do 10.-12. století s možným výskytem ve 13.14. století (Zimmermann 2000, 75, Tafel 24). Uvedené datování potvrzují také nálezy z jiných lokalit, napřr z Hradišt'ka u Davle (Richter 1982, 165), či výrazné zastoupení těchto hrotů na hradě Freudenštejn z druhé poloviny 13. až první poloviny 14. století (Kouřil-Prix-Wihoda 2000, 88, obr. 53-55).

Jediný exemplář reprezentuje hroty s tulejí (obr. 7:3), konkrétně typ B2a (Durdík 1972, obr. 3), typu B IIa (Krajíc 2003, obr. 150), popř. typu T 2-5 (Zimmermann 2000, 51-53) s delší dobou používání (Zimmermann 2000, 53), v našich podmínkách s těžištěm výskytu ve 14.-15. století (Krajíc 2003, 187) odpovídajícím masovému nástupu používání samostř́lů. 


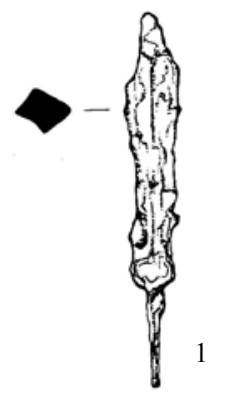

$-$
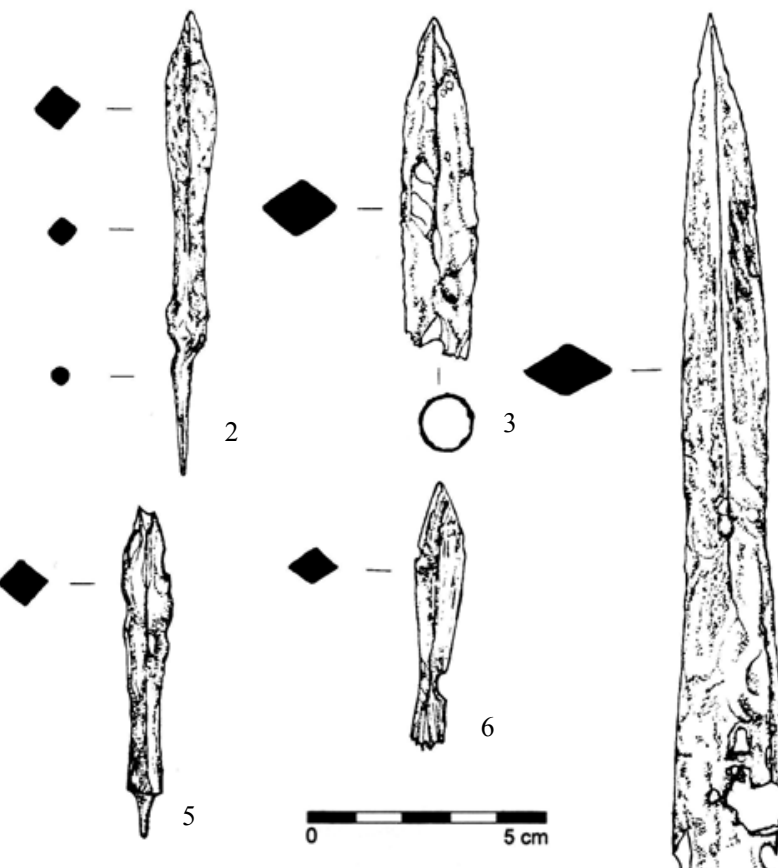

4
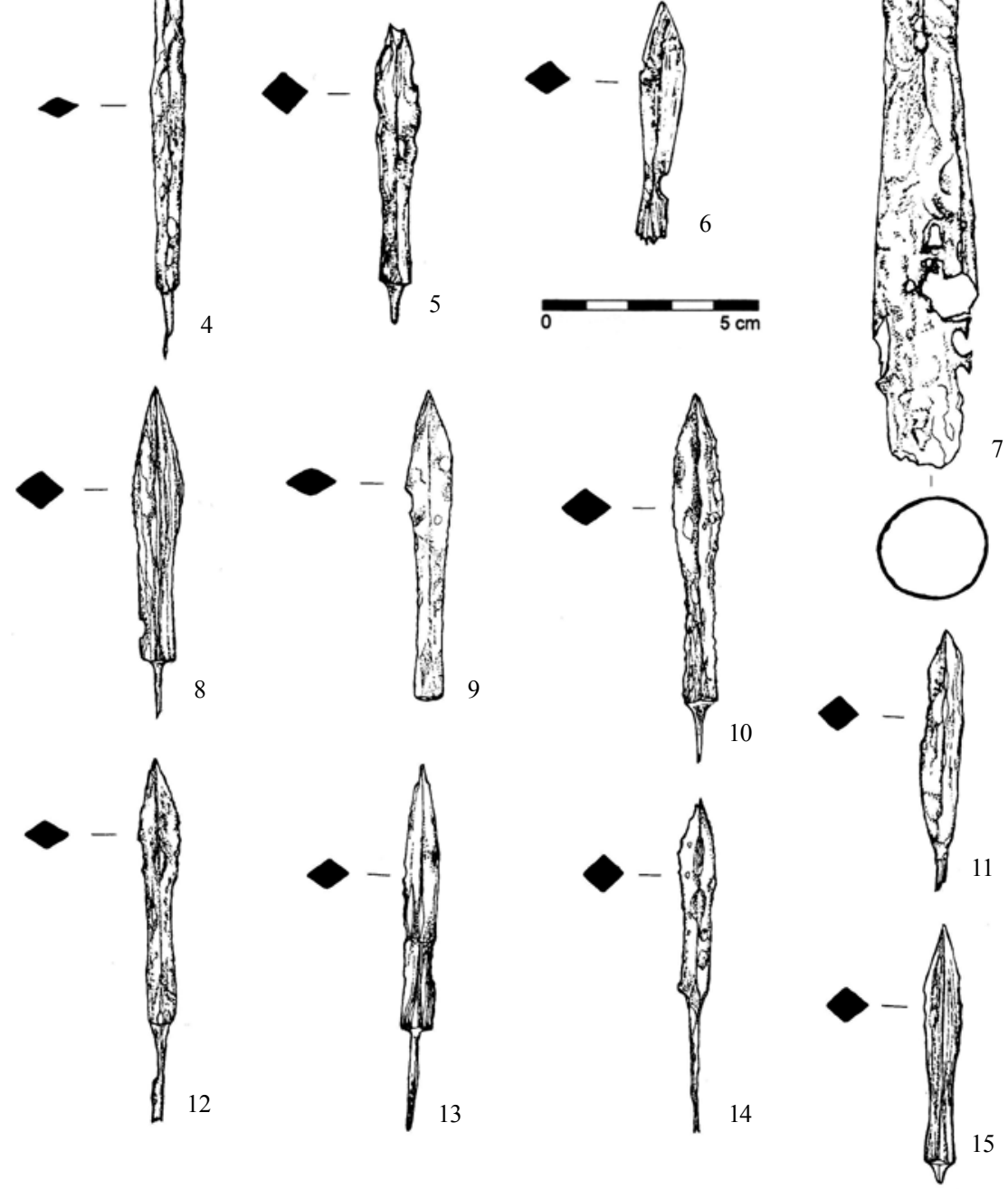

Obr. 7. České Libchavy. Nálezy militarií z tvrziště. 7 - hrot kopí, 1-6, 8-15 - hroty šípů (vše železo). Kresba M. Schindlerová. Abb. 7. České Libchavy. Militariafunde von der Festungsstätte. 7 - Lanzenspitze, 1-6, 8-15- Pfeilspitzen (alles Eisen). Zeichnung M. Schindlerová. 
$\mathrm{K}$ militariím můžeme kromě hrotů šípů s jistotou přiřadit ještě hrot kopí s rozšiřující se tulejí, bohužel odkorodovanou, takže neznáme přesný tvar železné části zbraně, a poměrně štíhlým listem rombického př́ičného průřezu nedosahujícím šířky tuleje (obr. 7:7). Zeštíhlování listu je reakcí na zlepšující se ochranu bojovníků ochrannou zbrojí, takovéto zbraně lze proto považovat za typologicky mladší. To potvrzují podobné nálezy ze zánikového horizontu na hradě Rokštejn (vlastní hrot bez tuleje je zde poněkud delší, Měřínský 1991, obr. 4:1; 2007, obr. 60:10) či ze zaniklých Konůvek (Měchurová 1997, 96, tab. LVI:5). Zajímavé srovnání nabízí také hrot z hradů Templštejn (Kouřil 1979, 135, obr. 3:11) a Bradlo (Hejna 1974, 396, obr. 13:1), které jsou však kratší. Že v takovýchto závěrech musíme být ovšem opatrní, ukazuje podobná zbraň z tvrziště v Semonicích datovaná již do přelomu 13. a 14. století (Huml 1967, 36, IX:6).

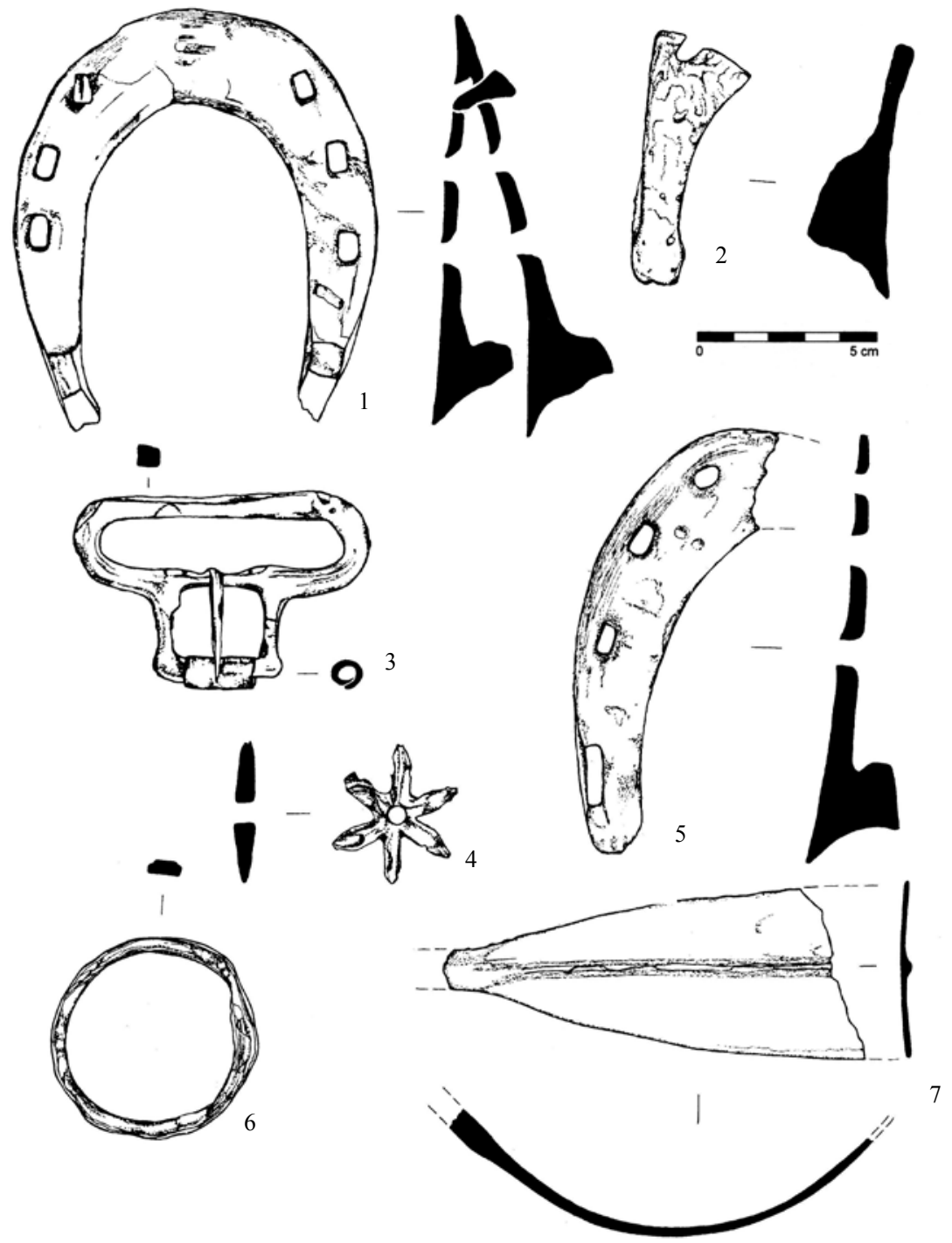

Obr. 8. České Libchavy. Militaria, výstroj koně a jezdce a neurčený předmět z tvrziště. 1-2, 5 - podkovy, 3 - přezka, 4 - kolečko ostruhy, 6 - kruh, 7 - zlomek třmene (vše železo). Kresba M. Schindlerová.

Abb. 8. České Libchavy. Militaria, Reitzubehör und ein unbestimmter Gegenstand von der Festungsstätte. 1-2, 5 - Hufeisen, 3 - Schnalle, 4 - Sporenrädchen, 6 - Ring, 7 - Bügelfragment (alles Eisen). Zeichnung M. Schindlerová. 
Fragment třmene původně kruhového tvaru (obr. 8:7) řadíme mezi militaria podmíněně, protože s tímto tvarem se ve vrcholném středověku setkáváme u samostř́llů, u nichž jako nášlapný třmen sloužil k napínání tětivy, vzhledem ke stavu dochování však nelze vyloučit ani možnost, že jde o zlomek vakovitého jezdeckého třmenu (Swiętosławski 1990, ryc. 18; Krajíc 2003, 116, obr. 102).

\section{Výstroj koně a jezdce} (obr. 8:2)

1. zlomek ramene podkovy s ozubem, $68 \times 28 \times 22 \mathrm{~mm}$, ve splachové vrstvě s keramikou

6. kolečko ostruhy se šesti paprsky, průměr $46 \mathrm{~mm}$, výška $9 \mathrm{~mm}, \mathrm{hl} .14 \mathrm{~cm}$, z toho $10 \mathrm{~cm}$ v okrovošedém rozpadlém skalním podloží vně tvrziště (obr. 8:4)

7. celá podkova s ozuby bez hmatce, $111 \times 99 \times 24 \mathrm{~mm}$, hl. $6 \mathrm{~cm}$ v okrovošedém rozpadlém skalním podloží v kořenech třešně či višně na SZ svahu akropole (obr. 8:1)

8. část podkovy s ozubem, $120 \times 31 \times 24 \mathrm{~mm}$, hl. $30 \mathrm{~cm}$ v kamenné destrukci na odvráceném svahu valu vně tvrziště (obr. 8:5)

9. přezka s trnem, $57 \times 81 \times 18 \mathrm{~mm}$, hl. $30 \mathrm{~cm}(25 \mathrm{~cm}$ kamenná destrukce $+5 \mathrm{~cm}$ okrovošedé rozpadlé skalní podloží) při patě valu vně areálu tvrziště (obr. 8:3)

Jedním celým exemplářem a dvěma zlomky máme zastoupeny podkovy. Celá podkova (obr. 8:1) náleží k typu 4d (Krajíc 2003, 104-105, obr. 95, 96), respektive typu VI/4 (Kaźmierczyk 1978, 97-103) s datací do druhé poloviny 13. až do 15. století. Polovinu podkovy (obr. 8:5) typu 6d (Krajíc 2003, 104-105, obr. 95, 96), popř. typu VI/2 (Kaźmierczyk 1978, 89-97), lze datovat analogicky. Část ramene poslední podkovy snad náleží k typu 6c (Krajíc 2003, 104-105, obr. 95, 96), popř. VI/1 (Kaźmierczyk 1978, 86-89), rovněž s analogickou datací.

Ostruhy bohužel reprezentuje pouze kolečko o šesti paprscích (obr. 8:4). Absenci ostruh musíme litovat o to více, že v rámci železných vrcholně středověkých artefaktů náleží k předmětům relativně chronologicky citlivým, což ovšem není př́ípad samotného kolečka.

Chronologicky irelevantní se jeví i masivní přezka (obr. 8:3) představující součást řemení koňského postroje. Stejně jsou interpretovány analogické nálezy z Pfaffenschlagu (Nekuda 1975, 138, obr. 139:3), Vízmburku (Hejna 1983, 496, obr. 5:1), Vildštejna (Durdík-Frolík 1993, 58, obr. 17:9) a Sezimova Ústí (Krajíc 2003, 128, tab. 107:11745), stejná přezka pochází i z Týřova (Durdík 1976, tab. IX:27).

\section{Zemědělské nářradí}

4. zlomek čepele srpu, $104 \times 19 \times 6 \mathrm{~mm}$, svah obdélné deprese, hl. $16 \mathrm{~cm}$ v rozpadlém okrovošedém skalním podloží (obr. 9:3)

5. zlomek okutí rýče či lopaty, $160 \times 52 \times 10 \mathrm{~mm}$, strmý svah pod severním nárožím areálu pod listím (obr. 9:1)

16. hřeb z bran, $146 \times 26 \times 20 \mathrm{~mm}$, pod listím u paty stromu (obr. 9:2)

Zemědělské nářadí nepatří $\mathrm{k}$ chronologicky citlivým předmětům, protože $\mathrm{v}$ takřka nezměněné podobě je použíáno až hluboko do novověku, což bez výjimky platí pro všechny tři prezentované artefakty.

Zakřivený zlomek klínovitého příčného průřezu (obr. 9:3) nepochybně představuje zlomek srpu, jehož další typologická klasifikace (Beranová 1957) není pro špatný stav dochování možná. Nálezy srpů a jejich zlomků patří k častým archeologickým nálezům s řadou analogií.

Předmět č. 16 lze spolehlivě klasifikovat na základě naseknutých hran v horní (nejširší) části předmětu (obr. 9:2) jako hřeb z bran, opět s množstvím analogií (Krajíc 2003, 135-136). Jeho nález pod listím při patě stromu celkem spolehlivě dokládá uložení v druhotné poloze, protože pohození k patě stromu je častý způsob nakládání s odmítnutými nálezy při nelegálním používání detektorů. 
Nejzajímavějším předmětem, který můžeme spojovat nejen se zemědělstvím, ale i s řemesly, je zlomek okutí rýče či lopaty (obr. 9:1) nalezený na svahu pod listím. Na místo nálezu se opět mohl dostat $\mathrm{v}$ důsledku nelegální detektorové činnosti, stejně jako erozní činností. S okutími rýčů a lopat vyskytujícími se v různých typech (Musil 2010, obr. 1) se v archeologických nálezech nesetkáváme př́liš často (Musil 2010, 165). Okutí z Českých Libchav tak rozšiřuje dosud

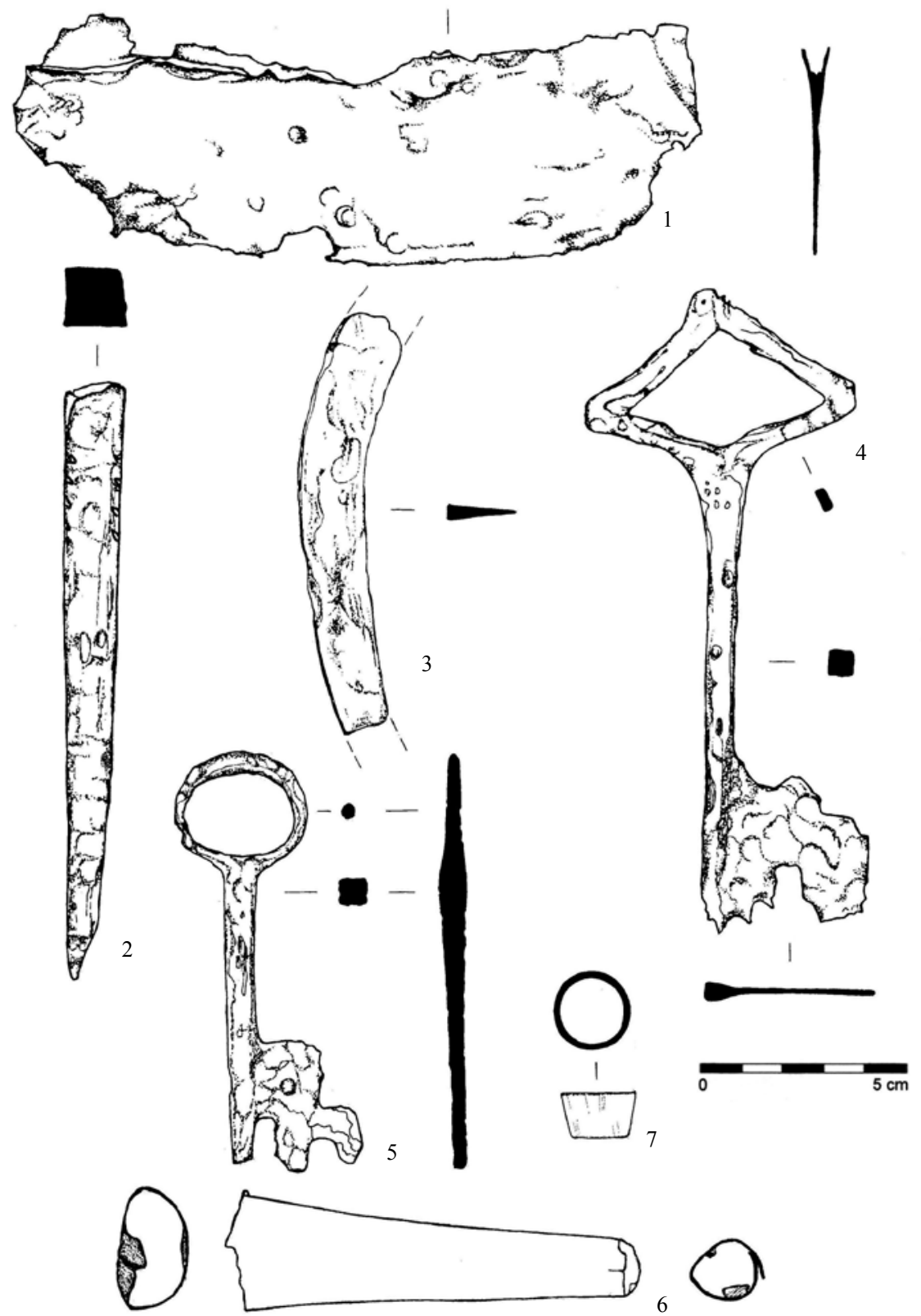

Obr. 9. České Libchavy. Zemědělské nářadí, stavební kování a neurčené předměty. 1 - část okutí lopaty či rýče, 2 - zub z bran, 3 - zlomek čepele srpu, 4-5 - otočné klíče, 6-7 - neurčené předměty (1-5 - železo, 6-7 - barevný kov). Kresba M. Schindlerová.

Abb. 9. České Libchavy. Ackerbaugeräte, Baubeschläge und unbestimmte Gegenstände. 1 - Schaufel- oder Spatenteil, 2 - Zinken einer Egge, 3-Sichelfragment, 4-5-drehbare Schlüssel, 6-7 - unbestimmte Gegenstände (1-5 - Eisen, 6-7 - Buntmetall). Zeichnung M. Schindlerová. 
nevelkou kolekci okutí z Čech (Krajíc 2003, 138-139 s další literaturou; pro východní Čechy Musil 2004; 2008; 2010; Drnovský 2012, 208-209, obr. 22:1).

\section{Stavební kování}

12. otočný klíč s kruhovým okem, $106 \times 35 \times 10 \mathrm{~mm}$, hl. $18 \mathrm{~cm}$, z toho $10 \mathrm{~cm}$ v okrovošedém rozpadlém skalním podloží (obr. 9:5)

13. otočený klíč s kosočtvercovým okem, $167 \times 69 \times 11 \mathrm{~mm}, \mathrm{hl} .11 \mathrm{~cm}$ v okrovošedém rozpadlém skalním podloží mezi kameny (do $10 \mathrm{~cm}$; obr. 9:4)

Pokud pomineme hřeby zjištované a ponechávané na místě v areálu tvrziště, reprezentují stavební kování (poněkud překvapivě) pouze dva klíče, přičemž v obou případech jde o reprezentanty otočných klíčů. Klíč s kruhovým okem a plným dříkem náleží $\mathrm{k}$ typu VIII podle R. Krajíce (1991, 332-333, obr. 9; 2003, 92, obr. 91). S klíči tohoto typu se setkáváme od raného středověku po 14. století, kdy postupně převládají klíče s dutým dříkem a prostým kruhovým okem, až nakonec je kruhové oko postupně opatřováno prolamovanou výzdobou (Klíma 1980, obr. 41; Slivka 1981, 238-239; Krajíc 1991, obr. 10; 2003).

Klíč s kosočtverečnou hlavou náleží k typu IX (Krajíc 1991, 332-333, obr. 9; 2003, 92, obr. 91). Proti datování těchto klíčů až do 14. století se již počátkem 60. let minulého století na základě nálezů ze Sekanky postavil M. Richter (1961), což další nálezy plně potvrdily. Klíč z objektu v domě čp. 241/I na Starém Městě pražském pak posouvá výskyt těchto kličů na našem území přinejmenším do první čtvrtiny 13. století (Dragoun 1992).

\section{Ostatni}

11. železný kruh, průměr $56 \mathrm{~mm}$, výška $12 \mathrm{~mm}$, hl. $10 \mathrm{~cm}$, z toho $8 \mathrm{~cm}$ v okrovošedém rozpadlém skalním podloží (obr. 8:6)

14. kornoutovitý předmět stočený z plechu z barevného kovu, $99 \times 27 \times 19 \mathrm{~mm}$, hl. $15 \mathrm{~cm}$ na rozhraní humusové vrstvy a rozpadlého okrovošedého skalního podloží (obr. 9:6)

15. kónický válcovitý předmět ze slitiny mědi, průměr $20 \mathrm{~mm}$, výška $12 \mathrm{~mm}$, hl. $14 \mathrm{~cm}$, z toho $4 \mathrm{~cm}$ v okrovošedém rozpadlém skalním podloží (obr. 9:7)

Soubor kovových předmětů doplňuje železný kruh (obr. 8:6), jehož funkční určení je problematické, může jít o součást stíhlového udidla, stejně jako o součást vozu atd. Neurčitelný je i kónický válcovitý předmět připomínající lotové závaží (obr. 9:7), který však nemá dno a je otevřený z obou stran. U kornoutovitého předmětu stočeného z plechu (obr. 9:6) není zřrejmý materiál, $\mathrm{z}$ něhož je zhotoven, př́slušnost $\mathrm{k}$ vrcholnému středověku zůstává i vzhledem k nálezu na rozhraní humusové vrstvy a podloží otevřená.

Jak z prostorové distribuce kovových předmětů vyplývá (obr. 10,11), můžeme všechny nalezené předměty důvodně považovat za vybavení tvrze, popř. za ztráty, k nimž došlo v době užívání tvrze. Získaný inventář (ovšem redukovaný nelegálními aktivitami) představuje v zásadě běžné vybavení drobného šlechtického sídla, chybí snad pouze předměty jednoznačně související s řemeslnou činností, což však může být odrazem relativně nízké kvantity movitých nálezů. Kovové artefakty v areálu tvrziště byly s výjimkou předmětů vynesených na povrch nelegální činností či erozí zachyceny v humusové vrstvě či ve vrstvě charakteru rozpadlého opukového podloží, na němž byla tvrz vybudována, zahloubené objekty ani zvrstvení nebyly přes veškerou pozornost zjištěny ani v jediném př́ípadě. Věžovitou stavbu postavenou z neznámého stavebního materiálu, po níž zůstal pouze zahloubený suterén (koncentrace keramiky v tomto prostoru určitě nebude náhodná), tak pravděpodobně doprovázela pouze lehká zástavba, jistotu však může přinést pouze plošný archeologický výzkum.

V širším okolí tvrze nebyly zjištěny žádné jiné aktivity, at' již vojenské, které by dokládaly boj, nebo hospodářské. Tuto situaci nelze vysvětlit pouhým vykradením lokality, protože by v případě hospodářsky využívaného předpolí na místě zůstaly alespoň hřeby, prrípadně některé 


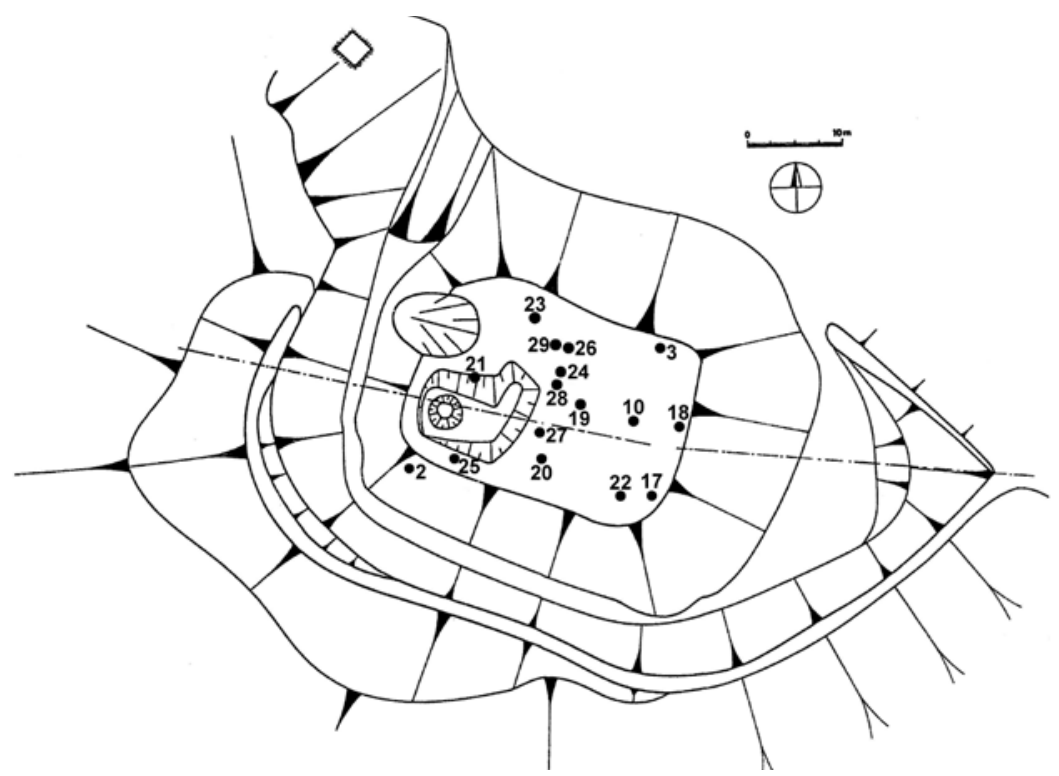

Obr. 10. České Libchavy. Prostorová lokalizace nálezů militarií v areálu tvrziště. Plán podle Cejpová 2003, upraveno.

Abb. 10. České Libchavy. Räumliche Lokalisierung der Militariafunde auf dem Gelände der Festungsstätte. Planskizze nach Cejpová 2003, modifiziert.

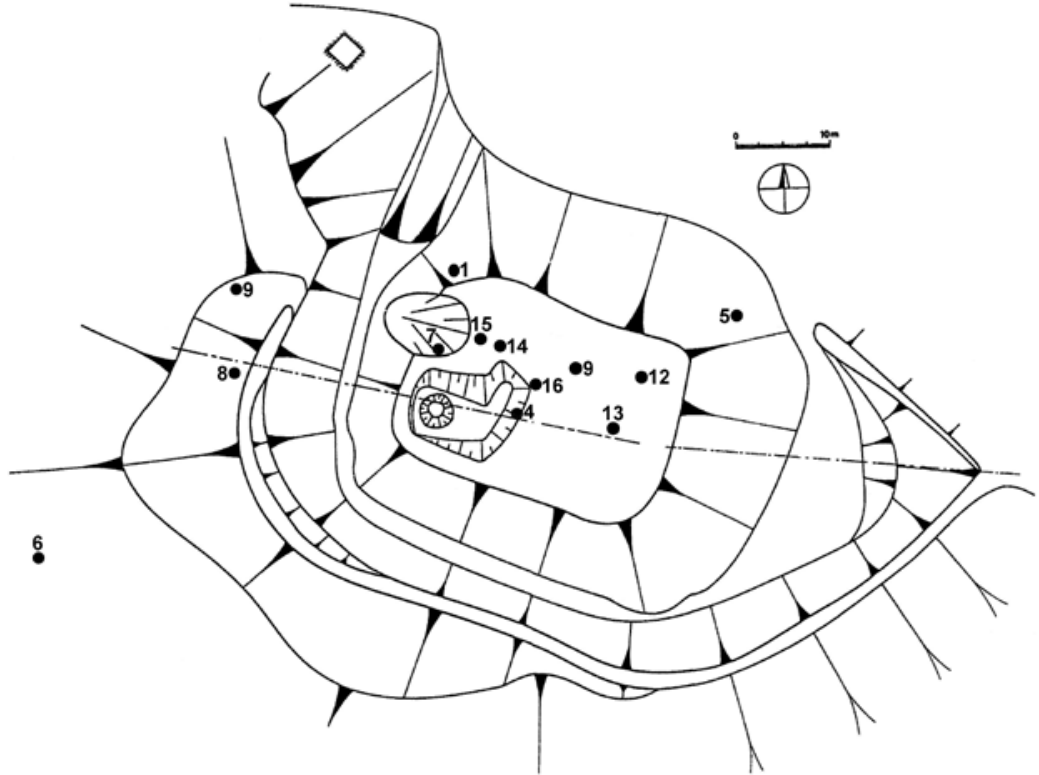

Obr. 11. České Libchavy. Prostorová lokalizace výstroje jezdce a koně, zemědělského nářadí, stavebního kování a neurčených předmětů v areálu tvrziště a jeho bezprostř̌edního okolí. Plán podle Cejpová 2003, upraveno.

Abb. 11. České Libchavy. Räumliche Lokalisierung des Reitzubehörs, der Ackerbaugeräte, Baubeschläge und unbestimmten Gegenstände auf dem Gelände der Festungsstätte und in ihrer unmittelbaren Umgebung. Planskizze nach Cejpová 2003, modifiziert.

další sběratelsky méně lukrativní předměty. Předpolí tvrziště bylo pravděpodobně neosídlené, existence předhradí (Musil 1995, 21) se tak na základě detektorového průzkumu jeví jako nepravděpodobná. Absence nálezů platí i pro prostor komunikace a jejího okolí, kde jsme rovněž nenašli žádné archeologicky relevantní předměty. V tomto př́ípadě už navždy zůstane otázkou, 
zda to můžeme přičíst rabovacím aktivitám, či zda se zde žádné kovové předměty nikdy nenacházely, pravda bude nejspíš někde uprostřed.

Prospekce v areálu tvrziště v Českých Libchavách tak i přes citelné narušení lokality rabováním s pomocí detektorů kovů (aniž by bylo možné byt' jenom odhadnout míru redukce pramenů vyrobených $\mathrm{z}$ kovu) a omezené množství získaných movitých nálezů přinesla některá nová zjištění. Především je to nápadná disproporce mezi výpovědí písemných a hmotných pramenů. Zatímco v písemných pramenech je tvrz výslovně připomínána až $\mathrm{k}$ roku 1543, movité nálezy signalizují osídlení lokality již ve 14. století, můžeme dokonce reálně uvažovat již o první polovině tohoto věku (výskyt tuhové keramiky, přítomnost slídy v keramické hmotě, převaha subtilních hrotů šípů s trnem, otočné klíče s plným dříkem a kruhovým či kosočtverečným okem), byt' to jednoznačně a nezpochybnitelně na základě získaných nálezů prokázat nelze. Existenci tvrze v první polovině 15 . století doloženou v písemných pramenech predikáty pak v hmotných pramenech spolehlivě identifikovat neumíme, jistě ale chybí vyspělá keramika závěru 15 . století. Ani náznakem se v nálezech neobjevují novověké předměty, ač se zánikový horizont v nálezech nezř́ídka projevuje nejvýrazněji. Doba vzniku, ale i zániku tvrze se tak jeví časnější, než dokládají písemné prameny. $\mathrm{O}$ to více musíme litovat absence numismatického materiálu, který by mohl vnést do dané problematiky více světla. Nezbývá proto, než se zatím spokojit s konstatováním, že pravděpodobné časnější založení tvrze nenašlo odraz v dochovaných písemných pramenech a absence novověkých nálezů patrně dokládá pokles významu lokality v tomto období. Analogické stáří můžeme předpokládat i pro relikt zahloubené komunikace, $\mathrm{v}$ tomto prŕpadě však bohužel jde o hypotézu bez opory v jakýchkoliv pramenech vyjma dochovaného reliktu cesty samé.

Prospekce dále signalizuje pouze jednoduchou lehčí zástavbu v okolí předpokládané věžovité budovy tvrze se zahloubeným suterénem - bez plošného výzkumu však stále půjde o pouhou hypotézu. Aplikace detektorů kovů pak rovněž hovoří pro absenci osídleného předpolí či předhradí studované fortifikace, stejně tak nemáme doloženy žádné vojenské události v okolí tvrziště.

\section{Prameny}

CDB II: Codex diplomaticus et epistolaris regni Bohemiae V/1 (Friedrich, G., ed.). Praha 1912.

\section{Literatura}

BERANOVÁ, M., 1957: Slovanské žňové nástroje v 6.-12. století - Славянские жатвенные орудия VI - XII вв., PA XLVIII, 99-117.

BURIAN, V., 1981: Nálezy jezdeckých třmenů z období 1340-1425 na hradě Tepenci a v dolanské Kartouzce, Zprávy Krajského vlastivědného muzea v Olomouci, č. 212, 25-28.

CEJPOVÁ, M., 2003: Tvrziště České Libchavy, k. ú. České Libchavy, okres Ústí nad Orlicí, Zpravodaj muzea v Hradci Králové 29, 248-254.

DRAGOUN, Z., 1992: Klíče z domu čp. 241/I v Husově ulici na Starém Městě pražském, SbSPS 3, 59-66.

DRNOVSKÝ, P., 2012: „Tvrz“ v Třebověticích. Hmotná kultura středověkého a raně novověkého sídla ve východních Čechách - „The Fortified Manor“ in Třebovětice. Material Culture od Medieval and Early Modern Period Residence in Eastern Bohemia, Studia Mediaevalia Pragensia 11, 177-226.

DURDÍK, T., 1972: K problematice středověkých šipek v Československu, Zpravodaj klubu vojenské historie 2, 4-6; 3, 5-9.

- 1976: Nálezy z hradu Týřova I. Katalog starších sbírek. Zprávy Čs. společnosti archeologické při Čs. akademii věd XVIII/3-6. Praha - Nitra - Brno.

DURDÍK, T.-FROLÍK, J., 1993: Hrad Vildštejn na Chrudimsku - Die Burg Vildštejn bei Chrudim, CB 3, 47-72.

HEJNA, A., 1974: Bradlo u Hostinného nad Labem. Příspěvek k výzkumu opevněných sídel v severovýchodních Čechách - Die Feste auf Bradlo bei Hostinné n. L. (Arnau an der Elbe) - ein Beitrag zur Burgenforschungen in Nordostböhmen, PA LXV, 365-418. 
- 1983: Kovový nálezový inventář z hradu Vizmburku, k. ú. Havlovice, o. Trutnov - Das Fundinventar metallischer Gegenstände aus Burg Vizmburg, Katastralgemeinde Havlovice, Bez. Trutnov, AH 8, 491-501.

HUML, V., 1967: Zaniklá tvrz Semonice. Fontes Musei Reginaehradecensis - Supplementum II. Hradec Králové.

KAŹMIERCZYK, J., 1978: Podkowy na Śląsku w X-XIV wieku. Wrocław - Warszawa - Kraków - Gdańsk.

KLÍMA, B., 1980: Zámečnická práce staromoravských kovářů v Mikulčicích. Praha.

KOŠŤÁL, J. a kol., 2013: Vízmburk. Př́íběh ztraceného hradu. Havlovice.

KOUŘIL, P., 1979: Archeologické nálezy z hradu Templštejnu (železné předměty) - Archäologische Funde aus Burg Templštejn (eiserne Gegenstände), AH 4, 129-140.

KOUŘIL, P.-PRIX, D.-WIHODA, M., 2000: Hrady českého Slezska. Brno - Opava.

KRAJÍC, R., 1991: Stavební železo a uzavírací mechanismy na vrcholně středověkých lokalitách Táborska - Eiserne Baubeschläge und Verschließungsmechanismen von den hochmittelalterlichen Lokalitäten in der Gegend von Tábor, AH 16, 323-344.

- 2003: Sezimovo Ústí. Archeologie středověkého poddanského města 3. Kovárna v Sezimově Ústí a analýza výrobků ze železa, díl I. Praha - Sezimovo Ústí - Tábor.

MĚCHUROVÁ, Z., 1997: Konůvky - zaniklá středověká ves ve Ždánickém lese. Studie Archeologického ústavu Akademie věd ČR v Brně XVII/1. Brno.

MĚŘÍNSKÝ, Z., 1991: Hrad Rokštejn a jeho úloha v předhusitském a husitském období. In: Sborník př́íspěvků k 555. výročí vyhlášení basilejských kompaktát v Jihlavě (Měřínský, Z., ed.), 65-82. Brno - Jihlava.

- 2007: Hrad Rokštejn. Dějiny, stavební vývoj a výsledky čtvrtstoletí archeologického výzkumu 19812006. Brtnice - Brno.

MILITKÝ, J.-VÍCH, D., 2010: Nález uherského dukátu Ladislava V. v Českých Libchavách (okr. Ústí nad Orlicí), Numismatický sborník 25, 169-170.

MUSIL, F., 1995: Hrady, tvrze a zámky okresu Ústí na Orlicí. Ústí nad Orlicí.

MUSIL, F.-GILAR, Š., 2002: K dějinám tvrze v Horních Libchavách, Pomezí Čech a Moravy 5, $243-250$.

MUSIL, J., 2004: Nálezy kování dřevěných rýčů ve východních Čechách se zvláštním zřetelem ke Chrudimsku, Chrudimský vlastivědný sborník 8, 43-54.

- 2008: Nové nálezy kování dřevěných rýčů a lopat z východních Čech, ČSPS 116, 240-246.

- 2010: Okutí dřevěného rýče a lopaty z Chrudimi - Hradební ulice, Chrudimský vlastivědný sborník 14, $165-179$.

NEKUDA, V., 1975: Pfaffenschlag. Zaniklá středověká ves u Slavonic. Brno.

NOHEJLOVÁ-PRÁTOVÁ, E., 1956: Nálezy mincí v Čechách, na Moravě a ve Slezsku II. Praha.

- 1957: Nálezy mincí v Čechách, na Moravě a ve Slezsku III. Praha.

PETRTYL, J., 1966: Nálezy mincí v oblasti Trstenické stezky na Litomyšlsku a jejich historická dokumentárnost. Litomyšl.

POCHE, E. a kol., 1977: Umělecké památky Čech A/J. Praha.

POLLA, B., 1962: Pamiatky hmotnej kultúry 15. storočia z Posádky pri Gajaroch, ZbSNM LVI - História 2, 107-140.

RICHTER, M., 1961: K počátkům tak zvaných gotických klíčů - Über den Beginn der sog. gotischen Schlüssel. In: Sborník Československé společnosti archeologické při ČSAV 1. K poctě akademika Jana Eisnera, 96-101. Brno.

- 1982: Hradišt'ko u Davle. Městečko ostrovského kláštera. Praha.

RUTTKAY, A., 1976: Waffen und Reiterausrüstung des 9. bis zur ersten Hälfte des 14. Jahrhunderts in der Slowakei II, SlArch XXIV, 245-395.

SEDLÁČEK, A., 1883: Hrady, zámky a tvrze království českého II. Hradecko. Praha.

SLIVKA, M., 1980: Stredoveké hutníctvo a kováčstvo na východnom Slovensku, Historica Carpatica XI, 218-288.

- 1981: Stredoveké hutníctvo a kováčstvo na východnom Slovensku, Historica Carpatica XII, 211-276.

SWIĘTOSŁAWSKI, W., 1990: Strzemiona średniowieczne z ziem Polski. Łódź.

VÍCH, D., 2006: Regionální muzeum ve Vysokém Mýtě. Katalog archeologické sbírky. Zprávy České archeologické společnosti. Supplément 62-63. Praha.

- 2014: Přehled archeologických akcí Regionálního muzea ve Vysokém Mýtě v roce 2012, Archeologie východních Čech 4/2012, 235-240.

ZIMMERMANN, B., 2000: Mittelalterliche Geschossspitzen. Kulturhistorische, archäologische und archäometallurgische Untersuchengen. Schweitzer Beiträge zur Kulturgeschichte und Archäologie des Mittelalters 26. Basel. 


\section{Zusammenfassung}

\section{Ein Beitrag zu den Erkenntnissen über die Festungsstätte in České Libchavy im Bezirk Ústí nad Orlicí}

Im Jahr 2008 wurde bei einem Kontrollbesuch der Fundstelle eine beträchtliche Störung der Festungsstätte in České Libchavy (Bez. Ústí nad Orlicí, Landkreis Pardubice, Abb. 1, 2) durch die illegale Benutzung von Metalldetektoren festgestellt, worauf zahlreiche Grabungslöcher vor allem im Bereich der Gräben hindeuten (Abb. 3). Im Hinblick auf die wenigen bislang über die Fundstelle bekannten Informationen entschied man, dort eine Oberflächenprospektion mitsamt der Nutzung von Metalldetektoren durchzuführen. Außerhalb der eigentlichen Festungsstätte wurde auch einem eingetieften Verkehrswegerelikt in unmittelbarer Nähe der Fundstätte Beachtung geschenkt (Abb. 1, Ausschnitt; Abb. 4).

Insgesamt konnten in den Jahren 2008-2014 29 Metallgegenstände (Abb. 10, 11) und 76 Keramikfragmente gefunden werden. Die Keramik wurde überwiegend im Reduktionsbrand hergestellt, es kam auch Grafitkeramik sowie rotbemalte Keramik vor. Die Ränder werden vor allem durch eine innen gekehlte Krause repräsentiert.

In den Metallfunden sind Militaria (Pfeilspitzen, insgesamt 14 Stück, davon 13 subtile Dornspitzen, Abb. 7:1-2, 4-6, 8-15, und eine Tüllenspitze, Abb. 7:3, Lanzenspitze, Abb. 7:7, Fragment eines Bügels, bei dem nicht entschieden werden kann, ob es sich um den Bestandteil einer Armbrust oder um einen Steigbügel handelte, Abb. 8:7), Reitzubehör (Hufeisen, Abb. 8:1-2, 5, Schnalle, Abb. 8:3, Sporenrädchen, Abb. 8:4), Ackerbaugeräte (Schaufel- oder Spatenbeschlag, Abb. 9:1, Zinken einer Egge, Abb. 9:2, Sichelfragment, Abb. 9:3), Baubeschläge (Schlüssel, Abb. 9:4-5) und sonstiges (Abb. 8:6; 9:6-7) vertreten.

Auffällig ist vor allem das Missverhältnis zwischen den Aussagen der schriftlichen und materiellen Quellen. Während in den schriftlichen Quellen erst für das Jahr 1543 eine Feste erwähnt wird, signalisieren die beweglichen Funde, dass die Fundstelle bereits im 14. Jahrhundert besiedelt war, wobei man tatsächlich sogar bereits die erste Hälfte dieses Jahrhunderts in Betracht ziehen kann. Die in den schriftlichen Quellen belegte Existenz einer Feste in der ersten Hälfte des 15. Jahrhunderts lassen sich in den materiellen Quellen nicht zuverlässig durch Prädikate identifizieren, mit Sicherheit fehlt aber hochentwickelte Keramik vom Ende des 15. Jahrhunderts. In den Funden tauchen noch nicht einmal ansatzweise neuzeitliche Gegenstände auf, obwohl in den Funden der Untergangshorizont nicht selten am deutlichsten zum Ausdruck kommt. Sowohl Enstehungs- als auch Untergangszeit der Feste erscheinen somit früher gewesen zu sein als durch die schriftlichen Quellen belegt wird. Es bleibt uns deshalb nichts anderes übrig, als sich vorerst mit der Feststellung zu begnügen, dass die wahrscheinliche frühere Gründung der Feste sich in den erhaltenen schriftlichen Quellen nicht widerspiegelt und das Fehlen von neuzeitlichen Funden offensichtlich einen Bedeutungsrückgang der Fundstelle für diesen Zeitraum belegt. Ein vergleichbares Alter kann auch für das eingetiefte Verkehrswegerelikt angenommen werden, jedoch handelt es sich in dem Fall leider nur um eine Hypothese ohne Rückhalt in irgendwelchen Quellen mit Ausnahme des erhaltenen Relikts des Wegs selbst.

Die Prospektion signalisiert ferner nur eine einfache leichtere Bebauung in der Umgebung eines mutmaßlichen turmartigen Baues der Feste mit eingetieftem Untergeschoss, jedoch handelt es sich dabei ohne Flächengrabung auch weiterhin nur um eine bloße Hypothese. Die Ergebnisse des Einsatzes von Metalldetektoren sprechen dann ebenfalls für die fehlende Existenz eines besiedelten Vorfeldes oder einer Vorburg der untersuchten Befestigungsanlange, ebenso sind auch keine militärischen Ereignisse in der Umgebung der Festungsstätte belegt.

PhDr. David Vích, Regionální muzeum ve Vysokém Mýtě, Šemberova 125, 56601 Vysoké Mýto, dvich@centrum.cz 
